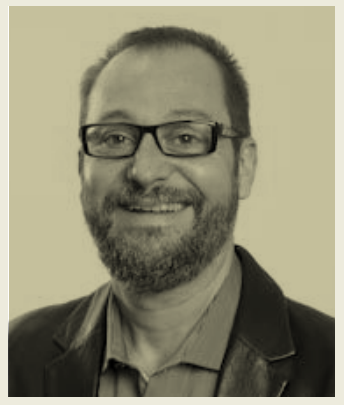

\title{
RISCO AMBIENTAL \\ NO SETOR FINANCEIRO: DO DISCURSO À PRÁTICA
}

O mercado financeiro é frequentemente acusado de não fazer sua parte no enfrentamento do risco climático e ambiental, mas a ficha parece começar a cair para gestores, investidores e reguladores. Larry Fink, chief executive officer (CEO) da BlackRock, maior gestora de ativos do mundo, alertou em sua carta de 2020 que "empresas, investidores e governo precisam se preparar para uma realocação significativa do capital" em virtude do risco climático. A pesquisa The importance of climate risks for institutional investors, publicada pela The Review of Financial Studies, mostra que a maioria dos gestores e diretores dos fundos de investimentos considera que a incorporação do risco climático beneficia o retorno dos investimentos. Assim, mais do que uma obrigação moral, a gestão do risco climático está ligada ao compromisso desses profissionais para com os investidores, otimizando seu retorno financeiro.

Nesse âmbito, o risco climático pode se materializar em riscos físicos, de transição e de imagem. O primeiro refere-se a desastres naturais, como as tempestades, inundações e secas; o segundo, a ativos que entrarão em desuso por conta de restrições naturais ou regulatórias, como reservas de petróleo que não serão extraídas; e o terceiro, à reputação da empresa (ou país) que detém um ativo ou produz algo considerado não sustentável.

Recentemente, o Banco Central (Bacen) anunciou a incorporação da dimensão de sustentabilidade à sua agenda de prioridades. É um passo importante na resposta ao conjunto de transformações estruturais da economia ligadas ao risco climático. Merece destaque a criação do Bureau Verde de crédito rural, que permitirá maior agilidade na certificação de sustentabilidade dos empréstimos ao agronegócio, reduzindo o risco ambiental desses ativos.

Tal conduta mostra-se relevante, já que a imagem externa do Brasil está bastante arranhada na área ambiental em razão do aumento do desmatamento e dos incêndios florestais no país, da condução atrapalhada da política ambiental e da recusa ao diálogo com a comunidade internacional. $\mathrm{O}$ dano de imagem ainda não se materializou de forma relevante nas exportações do agronegócio, nem na captação externa de financiamento para o setor, mas a possível imposição de sanções aos produtos brasileiros ou de restrições ao seu financiamento é um risco real.

O Bureau Verde facilitará a criação de títulos lastreados por esses empréstimos, melhorando as condições de financiamento do agronegócio. A certificação dos empréstimos verdes passa por ferramentas tecnológicas já em uso pelos bancos. Um exemplo é o monitoramento por satélite, em que o banco acompanha em tempo real a área de plantio ou a criação de gado que está sendo financiada. Esses sistemas emitem avisos quando o número de cabeças de gado é menor do que o estabelecido como garantia ao empréstimo, permitindo ação imediata e reduzindo a inadimplência. Esses dados serão cruzados com as informações existentes sobre desmatamento e podem servir na certificação de empréstimos verdes, ampliando as fontes de captação para o agronegócio e diminuindo seu custo de financiamento e os impactos ambientais.

Mas ainda estamos engatinhando na direção correta. Falta muito para que o discurso de preocupação com o risco climático da indústria financeira seja incorporado de fato às práticas do setor. Para que isso ocorra, a alta gestão deve compreender que os investimentos nessa área não são um custo para atender às demandas sociais ou uma obrigação moral, mas sim criadores de valor financeiro para seus acionistas.

\footnotetext{
PARA SABER MAIS:

- Philipp Krueger, Zacharias Sautner e Laura Starks. The importance of climate risks for institutional Investors. The Review of Financial Studies, v.33, n.3, 2020. Disponivel em: doi.org/10.1093//fs/hhz137
} 